Global Conferences Series:

Social Sciences, Education and Humanities (GCSSSEH), Volume 3, 2019

The $1^{\text {st }}$ International Conference on Education, Social Sciences and Humanities

DOI: https://doi.org/10.326/hum0214

\title{
Action Research as a Process for Improve Teaching and Learning in Table Tennis Class
}

\author{
Dony Andrijanto ${ }^{1 *}$, Dwi Lorry Juniarisca ${ }^{2}$, Heryanto Nur Muhammad ${ }^{3}$ \\ ${ }^{123}$ Dep. of Physical Education, Faculty of Sport Science, Universitas Negeri Surabaya, Surabaya, \\ Indonesia, \\ donyandrijanto@unesa.ac.id
}

\begin{abstract}
Action research is a method for implementing change starting from a spiral of plan, action, observation and reflection. The purpose of this article is to assess the effectiveness of action research used as a change process to improve the quality of teacher professionalism and the learning process in table tennis classes. This research is used to provide changes in teacher teaching skills and learning involving students, to reflect on and apply gradual change through reflection. The spiral method begins to plan, act, observe and reflect to apply gradual change through reflection. The results of action research provide good collaboration between teachers and students so as to create learning plans, learning methods, student worksheets and effective assessments in table tennis classes.
\end{abstract}

Keyword: Action research process, Teaching and Learning, Table Tennis

\section{Introduction}

Action Research

Action research is one of the important actions in an effort to improve the quality of human resources. Research into action is useful because it includes exceptions to teaching more effectively, deepens, broadens the teacher's understanding of the work they do. Action research is used as the development of teacher professionalism in the teaching and learning process (Jaipal Figg, 2011). The teacher occupies a strategic position having professionalism competencies (UUD No. 14 of 2005) to determine the implementation of a good learning process, where teacher competence can be seen from; (1) Plans; (2) Implementation; (3) Evaluation of learning used. The three teacher competencies are a unity that must be implemented by the teacher in order to encourage students to achieve learning goals. Although learning has been well planned but in the implementation process there are still various obstacles that hinder the achievement of learning objectives. Improvements must be made to the core problems experienced by teachers and students, so that the results are truly a solution to the problems that occur in the class (Robson 2002). Achievement of improved learning is carried out by teachers and students so that the

Copyright (C) 2019, the Authors. Published by Redwhite Press.

Page | 175

This is an open access article under the CC BY-NC license

(http://creativecommons.org/licenses/by-nc/4.0). 
implementation of learning involves students as learning subjects (Pultorak, 2014). The right approach is the use of classroom action research.

Table tennis class

Achievement of student competencies in the subject is one indicator of the quality of the learning process in Higher Education. The curriculum structure at Surabaya State University contains table tennis courses. The description of the table tennis lecture is the understanding and mastery of the theory and practice, tactics, strategies, rules of the table tennis game. Competency achievement is that students respect and appreciate the teachings of their religion; showing honesty, discipline, responsibility for learning in the environment and association; understanding the basic techniques of table tennis creates game modifications; teaching practice and combining basic techniques, refereeing and management of table tennis matches. Table tennis is a compulsory subject that must be implemented in every elementary school, junior high school and high school (Permendikbud No. 24 of 2016). Table tennis is a game of tennis that uses a table as a means of competition and bat as a bat (Juniarisca, D and Andijanto, D. 2016). The process of planning lectures in the table tennis class in the last two years has undergone changes from learning devices that make student textbooks, create student worksheets and evaluate student learning outcomes made by teachers without involving students. The focus of the study consists of three indicators, namely (1). Course preparation; (2) Implementation of lectures and; (3) evaluation of learning outcomes in table tennis classes. Action research is used by teachers to improve the quality of the teaching and learning process in table tennis classes which will directly involve students who are the subjects in the study. Professional teachers must be encouraged to try new ideas and conduct their own classroom action research on how well they work with their students in what conditions they work (Papastamis, Panitsidou, Giavrimis \& Papanis 2009).

\section{Method}

The method of using action research, action research is used as a process in change repeatedly and gradually to improve learning devices, implementation of learning, observation of learning and evaluation of learning in table tennis classes. Action research as an investigation. Each cycle consists of four stages, namely: (1) planning stage, (2) action phase, (3) development stage, (4) reflection phase for planning the next cycle (Mills (Craig A, M. 2012). Action research in this article describes descriptively the process of changing teaching in table tennis classes based on the implementation of learning by involving students directly. The instrument used was an interview sheet for students involved directly in the study. Questions about learning preparation, learning and evaluation of learning outcomes in table tennis classes. Participants in this study are students who program tennis courses, the academic year 2018/2017 in the Department of Physical Education, Faculty of Sports Science, Surabaya State University.

\section{Result and Discussion}

Action research is described as an action to improve a number of things in teaching and learning practices in table tennis classes. The process of changing research in spiral steps involves the opinions of students who are the main actors in the learning process as follows:

\section{Phase 1. 1Identification of current Practices}

Review of teaching practices to determine whether the performance that has been carried out has a positive impact on students and their learning outcomes. The researcher writes a detailed description of the learning experience in the table tennis class that has been done, so that the teacher can compare the teaching strategies that have been used and which will be used. The teaching method used focuses on 
knowledge competencies and finesse competencies. The teaching practice uses direct teaching methods. In the results of interviews with students who and the results of the analysis of the learning process that has been carried out, are explained as follows:

1. The teacher still dominates the learning process, occurs because students when presenting the material given only focus on theory, spend more time explaining the theory than the practice of mastering students' skills. Students need more time to practice table tennis skills. Giving questions related to the level of thinking of students is also still very low and not challenging. When practicing basic table tennis techniques that are still low, because students only make movements in accordance with the instructions of the teacher, without the development of modification games created by students.

2. The learning method is only listening to lectures, the use of media and demonstrations from the teacher comprehensively for students will be easier, but some students if only listening to material from the teacher will make it difficult for them to focus on learning because of monotonous activities.

Phase 1. 2 Planning

Based on the results of identification that have been obtained, the researcher made a planning change in each component of learning in the table tennis class:

1. The results of identification in the process of planning the suitability of learning implementation in accordance with the curriculum of 2 credits (100 minutes), added 1 credit (50 minutes) structured subject. Structured subjects are used to increase the mastery of skills in playing student table tennis.

2. Realizing the method used by the teacher is direct teaching. Changes are focused by using learning models using cooperative learning. Students are expected to be able to work in a learning activity in a team to deepen their knowledge by discussing and independently.

3. Learning evaluation is focused on the suitability of the material with the assignment during each learning period, so that the material is completed by students can be evaluated in each meeting by making notes on student learning outcomes.

Phase 1. 3 Implementation

Planning that has been made by the researcher will be applied with the implementation stage:

1. The teacher prepares the addition of 1 credit (50 minutes) structured carried out after students complete the learning activities, structured activities are focused on improving the skills of playing table tennis. this activity is held once a week.

2. Learning methods use cooperative learning. Students do the learning process not only focus on the teacher but more independently look for sources of table tennis material in groups or individually.

3. Evaluation of learning is carried out by making notes on student learning outcomes done individually so that after the recovery the teacher evaluates and knows the level of understanding of each student.

Phase 1. 4 Observation

Observation activities carried out to evaluate the implementation of ideas that have been designed involving colleagues, carried out and used to design development in the next cycle. The addition of structured learning 1 credits gets a very good impact from students so that structured learning within 1 week is carried out once with a focus only on the skills of playing table tennis. Cooperative learning methods are used to make students more independent in the learning process, but from observations of 
video results in each lesson, some students who do not complete individual tasks independently, do not complete student worksheets because I will not progress to presentations and be completed in groups. Learning evaluation is carried out in each meeting so that the teacher really knows the increase in knowledge and skills of each student from each meeting.

Phase 1.5 Reflection (Using successful actions)

Based on the results of the analysis reflected that the addition of learning hours (50 minutes) is needed if students to improve the skills of basic table tennis skills. Learning evaluation based on the opinions of students in the scope of cooperative learning teaching methods has not made all students actively involved in the group learning process. The plan for improvement will still use cooperative learning models with the peer teaching method. The use of the peer teaching method is expected to make students able to independently complete worksheets in groups and individuals. Student worksheets assign students to make table tennis lesson plans, students will directly play the role of being teachers and students. Changes in learning will be planned in the next cycle.

Phase 2. 1 Planning

The planning in the next step focuses on the learning model and method used. The application of cooperative learning models is used with the peer teaching method. Peer tutoring usually leads to better understanding of the academic concepts but it is more fruitful when the students having different ability levels work with each other. (Kunsch, Jitendra, \& Sood, 2007). The learning process of the teacher as a facilitator and learning design designer uses student worksheets. Planning is explained as follows: (1) Students are coordinated according to the group, the teacher divides the material according to the syllabus according to the number of meetings; (2) Each group makes a lesson plan with the guidance of the teacher, contains plans for teaching activities including opening, core activities and closing activities of the learning process that is designed; (3) Students make game modifications in accordance with the topics obtained; (4) Students learn more about how to teach and act as teachers and students.

\section{Phase 2.2 Implementation}

The process of implementing the use of cooperative learning models with the peer teaching method gives an impression to students. Students learn independently to design the lesson plan according to the topic given, determine the equipment to be used, determine the desired learning model, collaboration between groups so that each individual is involved in the lesson plan they design, determine the learning media, and determine the evaluation of learning that has been designed.

Phase 2.3 Observation

The action of observation is done by analysing the use of model learning with the lesson plan method. The results of learning carried out in table tennis class using peer teaching make students more active and independent. teaching experience and guiding friends to develop ways to communicate or discuss with friends, students can consider step by step decision making. This way students may expect smooth transitions between content taught at different grade levels ruling out gaps and differences primarily due to change of teachers and change of school (Gulick, 2011). It also develops students' metacognitive knowledge, where when they become teachers, students evaluate and control their own thinking as choices are made. Attract student teacher's attention to the description and choice of goals by 
binding them to decisions, also making teaching more responsive to the dynamics that occur during interactive teaching.

Phase 2.4 Reflection

The research approach requires that I switch from cooperative teaching to cooperative learning with the peer teaching method. Researchers use a democratic style to collaborate with students. The involvement of students as a collaborator in this study is very important in planning learning strategies and research results. Peer teaching can also offer students some spaces to think about the type of teacher they want to become and micro-teaching sessions can be used for experimenting with this type of teacher freely (Bell, 2007). The results show that after table tennis learning using cooperative learning models with peer teaching methods: DKL stated "I studied with the team and learned to hear suggestions from friends, I also evaluated the videos that I taught. I enjoy greater responsibility given to myself so that I am motivated ". The researchers also noted that this collaborative practice brought students closer and improved their listening skills and acting on them. The students voluntarily participated in the interview and regularly shared their ideas and thoughts about interventions, which I noted. It develops confidence when they realize the value of their role as a contribution to the collaborative process.

\section{Conclusions}

The use of new ideas allows teachers to decide on changes in teaching and learning activities, change is used to improve the insight and professionalism of a teacher. Collaboration between students and teachers is very important to decide on strategies and changes in teaching to improve the quality of teaching and learning in table tennis classes. The use of educational research is an important part of the learning process. Students enjoy the responsibility given, when they realize the value of their role in the learning process (acting as teachers and students) they indirectly focus on understanding the material that enhances their learning experience.

\section{References}

Bell, N.D. (2007). Microteaching: What is it that is going on here? Linguistics and Education, 18, $24-40$.

Craig A. M. (2012). Action Research Classrom, California: Thousand Oaks

Gulick, J. (2011) Implementing CSCOPE curriculum has been challenging, Avalanche Journal, Lubbock Online, retrieved from http://lubbockonline.com/education/2011-0310/implementingcscopecurriculum-has-been-challenging on March 05, 2019

Mills, G. (2011). Action research: A guide for teacher researcher (4th ed.). Boston, MA: Pearson.

McNiff, J. (2010). Action research for professional development: Concise advice for new (and experienced) action researchers. Dorset, England: September Books.

Juaniarisca,. D., Andrijanto. D (2017) Permaianan Tenis Meja. Unesa University Press. Surabaya

Jaipal, K., \& Figg, C. (2011). Collaboration action research approaches promoting professional development for elementary teachers. Educational Action Research, 19. Retrived form http://dx.doi.org/10.1080/09650792.2011.547688

Kunsch, C., Jitendra, A., \& Sood, S. (2007). The effects of peer-mediated instruction in mathematics for students with learning problems: A research synthesis. Learning Disabilities Research \& Practice, 22(1), 1-12

Letham, K., \& Peterson, B. (2009). Secondary Mathematics Cooperating Teachers' Perceptions of the Purpose of Student Teaching. Journal of Mathematics Teacher Education, 
RedWhitepress Global Conferences Series: Social Sciences, Education and Humanities (GCSSSEH), Volume 3, 2019

Papastamatis, A., Panitsidou, E. A., Giavrimis, P., \& Papanis, E. (2009). Facilitating teachers' and educators' effective professional development. Review of European studies.

Undang-undang Republik Indonesia nomor 14 tahun 2005 